\section{ОБЛІКОВО-АНАЛІТИЧНЕ ЗАБЕЗПЕЧЕННЯ УПРАВЛІННЯ ЛІКВІДНІСТЮ АГРАРНИХ ПІДПРИЕМСТВ ${ }^{\odot}$}

М.В. ПРАВДЮК, кандидат економічних наук, старший викладач кафедри обліку та оподаткування в галузях економіки, Вінницький національний аграрний університет (м. Вінниця)

Метою статті є виявлення проблемних аспектів ліквідності аграрних підприємств, аналіз динаміки показників ліквідності, визначення факторів впливу, облікового забезпечення ї̈ очінки та управління нею в умовах нестабільності аграрного бізнесу.

Методологічною основою дослідження $\epsilon$ сукупність методів наукового пізнання облікового забезпечення управління ліквідністю. Для розкриття теми використано загальнонаукові методи: абстракиії, формалізачії, ідеалізації, порівняння, функиіонального та статистичного аналізу.

Проаналізовано фінансовий стан аграрних підприємств за 2013-2017 рр., здійснено аналіз показників ліквідності на прикладі окремих аграрних підприємств. Оиінено зарубіжний досвід облікової оиінки ліквідності та обрано сфери, які можуть бути запозичені для розвитку методики визначення та управління ліквідністю.

На основі ичих досліджень запропоновано уточнене розуміння ліквідності з урахуванням специфіки діяльності аграрних підприємств, підкреслена необхідність перегляду нормативних значень коефічієнтів ліквідності для агропідприємств на рівні їх форм, видів, роду діяльності, регіону тощо. Запропоновано алгоритм обліковоаналітичного забезпечення управління ліквідністю. Уточнено вимоги до системи обліку в частині забезпечення збору даних для фінансового аналізу у розрізі ліквідності.

Очікується, щуо пропозиції, викладені у статті, сприятимуть частковому вирішенню проблем обліково-аналітичного забезпечення управління ліквідністю аграрних підприсмств.

Ключові слова: обліково-аналітичне забезпечення, аграрні підприємства, фінансові результати, управління, фінансова звітність, показники ліквідності.

Табл.: 7. Рис.: 3. Літ.: 16.

\title{
ACCOUNTING AND ANALYTICAL SUPPORT TO THE LIQUIDITY MANAGEMENT OF AGRICULTURAL ENTERPRISES
}

PRAVDIUK Maryna, Candidate of Economic Sciences, Senior Reader of the Department of Accounting and Taxation in the Economy, Vinnytsia National Agrarian University (Vinnytsia) 


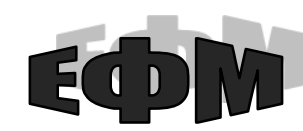

http://efm.vsau.org/

The purpose of the article is to identify the problematic aspects of liquidity of agricultural enterprises, the analysis of the dynamics of indicators of liquidity, the definition of the factors of influence on its assessment and management in conditions of instability of agricultural business.

The methodological basis of the research is a set of methods of scientific knowledge for accounting providing of liquidity management. In order to disclose the problem common scientific methods: abstraction, formalization, idealization, comparison, functional and statistical analysis were used.

The financial condition of agricultural enterprises for the years 2013-2017 were considered, the analysis of indicators of liquidity on the example of individual agricultural enterprises was made. Foreign experience in accounting evaluation of liquidity and certain areas that can be adopted for the development of methods for determining and liquidity management was studied.

On the base of the study revised understanding of liquidity with regard to the specifics of the activity of agricultural enterprises was suggested, the need to view the normative values of coefficients of liquidity to agricultural enterprises at the level of their forms, species of the genus activity, region, etc. was highlighted. The algorithm for accounting and analytical provision of liquidity management was proposed. Accounting system requirements in part of providing the data for financial analysis in terms of liquidity was specified.

It is expected that the proposals set out in the article, will partially solve the problems of the accounting and analytical provision of liquidity management of agricultural enterprises.

Key words: accounting and analytical support, agricultural businesses, financial results, management, financial statements, liquidity.

Tabl.: 7. Fig.: 3. Ref.: 16.

\title{
УЧЁТНО-АНАЛИТИЧЕСКОЕ ОБЕСПЕЧЕНИЕ УПРАВЛЕНИЯ ЛИКВИДНОСТЬЮ АГРАРНЫХ ПРЕДПРИЯТИЙ
}

\author{
ПРАВДЮК Марина Владимировна, \\ кандидат экономических наук, старший преподаватель \\ кафедры учёта и налогообложения в отраслях экономики, \\ Винницкий национальный аграрный университет
} (2. Винница)

Целью статьи является выявление проблемных аспектов ликвидности аграрных предприятий, анализ динамики показателей ликвидности, определение факторов влияния, учётного обеспечения её оценки и управления ею.

Методологической основой исследования является совокупность методов научного познания учётного обеспечения управления ликвидностью. Для раскрытия темы использованы общенаучные методы: абстракции, формализации, идеализачии, сравнения, функиионального и статистического анализа.

Оиенено финансовое состояние аграрных предприятий за 2013-2017 г2., осуществлен анализ показателей ликвидности на примере отдельных аграрных предприятий. Проанализирован зарубежный опыт учётной оченки ликвидности и избраны сферы, которые могут быть заимствованы для развития методики определения и управления ликвидностью. 
На основе этих исследований предложено уточнённое понимание ликвидности с учётом специфики деятельности аграрных предприятий, подчёркнута необходимость пересмотра нормативных значений коэффициентов ликвидности для агропредприятий на уровне их форм, видов, рода деятельности, региона и т.п. Предложен алгоритм учётно-аналитического обеспечения управления ликвидностью. Уточнены требования к системе учёта в части обеспечения сбора данных для финансового анализа в разрезе ликвидности.

Ожидается, что предложения, изложенные в статье, будут способствовать частичному решению проблем учётно-аналитического обеспечения управления ликвидностью аграрных предприятий.

Ключевые слова: учётно-аналитическое обеспечение, аграрные предприятия, финансовые результаты, управление, финансовая отчётность, показатели ликвидности.

Табл.: 7. Рис.: 3. Лит.: 16.

Постановка проблеми. Ліквідність як економічна категорія знаходиться в центрі уваги теоретичних і практичних досліджень. Особливої актуальності останніми роками набули питання щодо ії визначення, оцінки та управління, оскільки економічна криза дестабілізує фінансовий стан (табл. 1), що вимагає постійного контролю фінансових показників аграрних підприємств.

Таблиия 1

Фінансовий стан аграрних підприсмств України у 2012-2017 рр.

\begin{tabular}{|l|c|c|c|c|c|c|}
\hline & $\mathbf{2 0 1 2}$ & $\mathbf{2 0 1 3}$ & $\mathbf{2 0 1 4}$ & $\mathbf{2 0 1 5}$ & $\mathbf{2 0 1 6}$ & $\mathbf{2 0 1 7}$ \\
\hline Ресурси, млрд грн & 276651,8 & 313096,8 & 390607,0 & 685844,9 & 1537319,1 & 911614,1 \\
\hline $\begin{array}{l}\text { Чистий прибуток, млн } \\
\text { грн }\end{array}$ & 26787,2 & 14984,5 & 21481,3 & 102849,1 & 90613,2 & 68858,5 \\
\hline $\begin{array}{l}\text { Рентабельність } \\
\text { діяльності, \% }\end{array}$ & 21,7 & 11,3 & 20,6 & 41,7 & 32,4 & 22,4 \\
\hline Оборотні активи, \% & 63,2 & 62,3 & 68,5 & 75,0 & 85,8 & 70,1 \\
\hline Власний капітал, \% & 53,6 & 50,1 & 42,0 & 40,2 & 24,1 & 47,9 \\
\hline
\end{tabular}

Джерело: складено автором за даними Державної служби статистики

Нерівномірність розвитку, за даними табл. 1, простежується за всіма категоріями - ресурсами, чистим прибутком, рентабельністю, структурою балансу. Для зменшення негативного впливу дестабілізуючих факторів на рівень фінансів аграрних підприємств необхідний детальний аналіз активів.

При визначенні ліквідності основна проблема полягає в тому, що існують суттєві суперечності в трактуванні й розрахунку іiі показників та методики визначення, бази та джерел даних. Застосування різних підходів, своєю чергою, призводить до суперечливих результатів і хибних висновків.

Оскільки основою формування категорії є дані бухгалтерського обліку, то від якості обліково-аналітичного супроводження визначення ліквідності залежить ефективність управлінських рішень, а відтак і ефективність роботи підприємств. Тому необхідне наукове супроводження процесу обліково-аналітичного забезпечення управління ліквідністю, пошуки нових підходів.

Формулювання цілей статті. Метою дослідження є виявлення проблемних аспектів формування облікового забезпечення управління діяльності аграрних підприємств та наукове обгрунтування теоретико-методологічних положень для їх вирішення в умовах нестабільності аграрного бізнесу. 


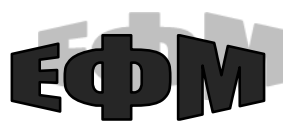

http://efm.vsau.org/

Аналіз останніх досліджень і публікацій. Проблеми обліково-аналітичного забезпечення досліджують: В. Жук, М. Дем’яненко, М. Пушкар, П. Саблук, Г. Калетнік [1; 2], І. Садовська, Н. Гудзенко [3], Н. Коваль, Т. Плахтій, Н. Здирко, В. Мазур, О. Томчук [4], Н. Трусова [5], Н. Танклевська [6], Т. Мулик [7], С. Халатур [8] та ін.

Аналіз цих джерел підтверджує актуальність проблеми, а також вказує на необхідність уточнення методичного інструментарію оцінки та управління ліквідністю засобами бухгалтерського обліку оскільки досі не вироблено єдиного підходу до того, чим є обліково-аналітичне забезпечення - процесом, системою показників звітності, кінцевим інформаційним продуктом щодо ліквідності i забезпечення управління нею. Це гальмує можливості визначення принципів його формування, особливо у контексті інформаційного забезпечення управління ліквідністю підприємств.

Серед проблем, що залишаються невирішеними, слід виділити питання визначення дефініції «обліково-аналітичне забезпечення», показників та балансу ліквідності, SWOT-аналізу факторів управління ліквідністю. Постає наукове завдання формування облікової інформації, яка б відповідала цільовим критеріям макро- та мікрорівнів управління ліквідністю в аграрному секторі.

Виклад основних результатів дослідження. Як зазначає Г. Калетнік, аграрна галузь української економіки є надійним фундаментом забезпечення продовольчої безпеки держави, базисом розширення ¥ї експортного потенціалу, джерелом задоволення внутрішнього попиту на сільськогосподарську продукцію та продукти харчування [1]. Тому для галузі важливе значення мають економічні методи управління, що виникли і розвиваються в процесі підприємницької діяльності, проявляються як об'єктивні економічні закони та певні економічні інтереси. Ученим розглядаються також проблеми ліквідності на макрорівні, для чого розроблено економіко-математичну модель визначення стійкості економіки на основі використання теорії нечіткої логіки та методу оптимізації - генетичного алгоритму [2, с. 24]. У системі фінансової стійкості провідне місце займає ліквідність. А найбільш повна реалізація управління цими процесами на рівні підприємств здійснюється через обліково-аналітичне забезпечення управління. У загальних рисах обліково-аналітичне забезпечення є процесом збору інформації за рахунок обліку та аналізу для цілей управління. Найбільш типові визначення терміну наведено у табл. 2 .

Табличя 2

Суть та роль обліково-аналітичного забезпечення у визначеннях вчених Вінницького національного аграрного університету

\begin{tabular}{|c|c|}
\hline Автори & Визначення \\
\hline 1 & 2 \\
\hline $\begin{array}{l}\text { Плахтій Т.Ф. (2016). Якість } \\
\text { у бухгалтерському обліку: } \\
\text { економічний аспект. }\end{array}$ & $\begin{array}{l}\text { Якість у бухгалтерському обліку слід розглядати } 3 \text { позиції } \\
\text { споживчої вартості досліджуваного об'єкта облікової науки } \\
\text { (облікової системи; облікової інформації; фінансової звітності } \\
\text { тощо), основною метою забезпечення якої є задоволення потреб } \\
\text { споживачів такого об'єкта (розробників системи; користувачів } \\
\text { облікової інформації; користувачів фінансової звітності тощо). }\end{array}$ \\
\hline $\begin{array}{l}\text { Корпанюк Т.М. (2016). } \\
\text { Фінансово-економічна } \\
\text { діагностика аграрних } \\
\text { підприємств } 3 \text { виробництва } \\
\text { біопалива. }\end{array}$ & $\begin{array}{l}\text { Починаючи процес стратегічного управління, слід передусім } \\
\text { визначити місію і цілі, завдяки яким підприємство може уявити } \\
\text { напрям розвитку свого бізнесу і своє майбутнє. Має бути } \\
\text { проведена експрес-діагностика фінансово-господарського стану } \\
\text { підприємства. }\end{array}$ \\
\hline
\end{tabular}


Продовження 2

\begin{tabular}{|c|c|}
\hline 1 & 2 \\
\hline $\begin{array}{lr}\text { Мулик Т.О., Мулик Я.І. } \\
\text { (2016). } & \text { Методичний } \\
\text { iнструментарій } & \text { аналізу } \\
\text { фінансової } & \text { безпеки } \\
\text { підприємств у } \quad \text { системі } \\
\text { економічних } & \text { аспектів } \\
\text { виробництва біопалива }\end{array}$ & $\begin{array}{l}\text { Формування механізму забезпечення фінансової безпеки } \\
\text { підприємств, який дасть можливість оцінювати іï рівень, } \\
\text { ідентифікувати ризики та загрози фінансовій безпеці, } \\
\text { розробляти та проводити превентивні заходи } 3 \text { метою їх } \\
\text { мінімізації, будувати стратегію розвитку підприємства. }\end{array}$ \\
\hline $\begin{array}{l}\text { Здирко Н.Г. }(2017) \text {. } \\
\text { Сучасний стан і тенденції } \\
\text { розвитку аудиторської } \\
\text { діяльності в Україні }\end{array}$ & $\begin{array}{l}\text { Обліково-аналітичні фактори: звірка взаємних розрахунків із } \\
\text { кредиторами (дебіторами); оцінка обсягів продажу; розрахунки } \\
\text { ліквідності; оцінка залежності від постачальників (покупців); } \\
\text { аналіз виконання сторонами умов договору. }\end{array}$ \\
\hline $\begin{array}{l}\text { Правдюк Н.Л. (2017). } \\
\text { Соціальні } \quad \text { аспекти } \\
\text { бухгалтерського обліку. }\end{array}$ & $\begin{array}{l}\text { Сучасні взаємовідносини суспільства і бізнесу сприяють } \\
\text { поглибленню ролі обліку у соціальному житті. Цей процес } \\
\text { відбувається за різними напрямками... } \\
\text { Ціль соціального напряму бухгалтерського обліку - створити } \\
\text { інформаційну систему, яка дозволяє будь-який факт } \\
\text { господарського життя підприємства зіставити з соціальними } \\
\text { потребами працівників, власників, акціонерів та суспільства. }\end{array}$ \\
\hline $\begin{array}{l}\text { Гудзенко Н.М., Коваль Н.І., } \\
\text { Плахтій Т.Ф. (2018). Вплив } \\
\text { iнформаційних потреб } \\
\text { користувачів на структуру } \\
\text { та наповнення фінансової } \\
\text { звітності }\end{array}$ & $\begin{array}{l}\text { Облік та звітність відходять від фіксування господарських } \\
\text { операцій та подій та набувають характеру перспективного } \\
\text { планування для визначення очікуваних результатів, розрахунку } \\
\text { доцільності залучення фінансових ресурсів. }\end{array}$ \\
\hline
\end{tabular}

Джерело: сформовано автором за публікаціями журналу «Економіка. Фінанси. Менеджмент: актуальні питання науки і практики. URL:http://efm.vsau.org/

На нашу думку, спираючись на проведені дослідження $[7 ; 9 ; 10]$ можна стверджувати, що обліково-аналітичне забезпечення - це документально обгрунтований процес добору економічних даних на потреби управління аграрних підприємств. Залежно від мети, він генерує дані обліку, аналізу і контролю для прийняття управлінських рішень і має різні ступені деталізації та ієрархії. Зібрана інформація може також бути основою подальшого узагальнення на основі формальної логіки та математичних моделей, що притаманно уже для макроекономічного рівня управління галуззю.

Методологія аналізу ліквідності підприємства включає розрахунок і аналіз абсолютних i відносних показників, що іiі характеризують. Щодо ліквідності підприємств, то загальновизнано, що це - їх здатність формувати достатні резерви платіжних засобів для виконання фінансових зобов'язань через перетворення активів у засоби платежу. Зокрема, у визначеннях дослідників термін наводиться з більшою чи меншою деталізацією.

Так, зазвичай, ліквідність характеризує механізм перетворення фінансових або матеріальних активів у грошові кошти з метою своєчасного виконання зобов'язань. Т. Чайка $з$ авторами зазначає, що термін «ліквідний» передбачає безперешкодне перетворення майна в засоби платежу. Чим менше час, необхідний для перетворення окремого виду активів, тим вище його ліквідність [11]. 
Таким чином, ліквідність підприємства - це його здатність перетворити активи на грошові кошти платежу для погашення зобов'язань. Ліквідне сільськогосподарське підприємство здатне підтримувати поточний фінансовий стан стійким, враховуючи специфіку функціонування сільського господарства та галузеву спеціалізацію.

Як зазначають дослідники, зокрема Н. Танклевська, базовими характеристиками є унікальність (визначається особливостями кожного конкретного підприємства та залежить від розмірів підприємства, його виробничо-технічних, фінансових, організаційних можливостей), відокремленість (незалежність від інших виробничих одиниць), комплексність (ліквідність усіх функціональних складових), ефективність та динамічність (забезпечення можливостей швидкої зміни послідовності дій та стратегії забезпечення ліквідності при зміні факторів та умов фінансового середовища) [6, с. 16]. Інші вчені вважають, що «показники ліквідності відображають рухливість активів, стійкість пасивів, відповідність здійснюваних активних і пасивних операцій, можливості підприємства в погашенні узятих зобов'язань» [11].

За найпоширенішими методиками для оцінки ліквідності підприємства використовуються коефіцієнти ліквідності (загальної, швидкої та абсолютної) (табл. 3). Для цих коефіцієнтів характерні варіація назв, методики розрахунку, нормативні значення, галузеві особливості.

За системою показників, наведених у табл. 3, проведено аналіз у табл. 4, 3 якого слідує, що аграрні підприємства у 2012 р. могли в поточний момент погасити свої короткострокові борги на $12 \%$ за даними коефіцієнта абсолютної ліквідності, а у 2017 році - тільки на 6\%. Значення не досягало нормативного показника за аналізований період.

Таблиия 3

Коефіціснти ліквідності та їх характеристики

\begin{tabular}{|c|c|c|}
\hline Коефіціснт & Характеристика & $\begin{array}{c}\text { Розрахунок, } \\
\text { джерела даних }\end{array}$ \\
\hline 1 & 2 & 3 \\
\hline $\begin{array}{l}\text { загальної } \\
\text { ліквідності }\end{array}$ & $\begin{array}{l}\text { здатність підприємства забезпечити свої } \\
\text { короткострокові зобов'язання } 3 \text { найбільш легко } \\
\text { реалізованої частини активів - оборотних коштів. } \\
\text { Дає найбільш загальну оцінку ліквідності активів. } \\
\text { Необхідно, щоб поточні активи перевищували } \\
\text { поточні зобов'язання. Норматив } 1,5-2,5 \text {, але не } \\
\text { менше 1. Значення коефіцієнта, рівне 1, } \\
\text { припускає рівність поточних активів і пасивів. } \\
\text { Якщо перевищує } 1 \text {, то підприємство володіє } \\
\text { значним обсягом вільних ресурсів }\end{array}$ & $\begin{array}{l}\text { Кзл= Оборотні активи/ } \\
\text { Поточні зобов’язання } \\
\text { Кзл= ф.1ряд1195 / } \\
\text { ф.1ряд.1695; } \\
\text { для підприємств та } \\
\text { суб'єктів малого } \\
\text { підприємництва за цими ж } \\
\text { кодами, ф.1-м }\end{array}$ \\
\hline $\begin{array}{l}\text { поточної } \\
\text { ліквідності }\end{array}$ & $\begin{array}{l}\text { показує, яку частину поточних зобов’язань } \\
\text { підприємство спроможне погасити за рахунок } \\
\text { найбільш ліквідних оборотних коштів - } \\
\text { грошових коштів та їх еквівалентів, фінансових } \\
\text { інвестицій та дебіторської заборгованості. } \\
\text { Платіжні можливості підприємства щодо } \\
\text { погашення поточних зобов’язань за умови } \\
\text { своєчасного здійснення розрахунків } 3 \\
\text { дебіторами. Теоретично значення достатнє, } \\
\text { якщо перевищує } 0,6\end{array}$ & $\begin{array}{l}\text { Кпл=(Оборотні активи - } \\
\text { запаси)/поточні активи } \\
\text { Кпл=ф.1(ряд.1195- } \\
\text { ряд.1100)/ ф.1ряд.1695; } \\
\text { для суб'єктів малого } \\
\text { підприємництва форма } \\
\text { звітності 1-м }\end{array}$ \\
\hline
\end{tabular}


Продовження табл. 3

\begin{tabular}{|l|l|l|}
\hline \multicolumn{1}{|c|}{ 1 } & \multicolumn{1}{|c|}{2} & \multicolumn{1}{|c|}{3} \\
\hline абсолютної & дозволяє визначити частку короткострокових & К.а.=Грошові \\
ліквідності & зобов’язань, що підприємство може погасити & активи/Поточні \\
& найближчим часом, не чекаючи оплати & 3обов'язання; \\
& дебіторської заборгованості й реалізації інших & Ка=ф.1 (ряд.1160+1165)/ \\
& активів. Теоретично значення достатнє, якщо & ф.1ряд.1695 \\
& перевищує 0,2-0,3. Високе значення показника & \\
& свідчить про нераціональне використання & \\
& фінансових ресурсів & \\
\hline чистий & необхідний для підтримки фінансової стійкості & Чок= поточні активи - \\
оборотний & підприємства, показує резерви для розширення & поточні пасиви; \\
капітал & діяльності. Рекомендовані значення:>0 & $\begin{array}{l}\text { Чок= ф.1.ряд.1195 - } \\
\text { ф.1.ряд.1695 }\end{array}$ \\
\hline
\end{tabular}

Джерело: складено на основі [11; 12]

Коефіцієнт поточної ліквідності показує, яка частина короткострокових зобов'язань погашається за рахунок наявних і майбутніх грошових надходжень та слугує для оцінки можливості погашення підприємством цих зобов'язань у разі його критичного стану.

Динаміка цього показника має позитивну тенденцію: якщо у 2012 р. - 0,2\%, що значно менше за нормативне значення, то у 2017 р. - 1,05\%, що знаходиться у межах нижньої норми.

Коефіцієнт загальної ліквідності характеризує ступінь покриття поточних зобов'язань поточними активами.

Аналіз динаміки цього показника свідчить, що, починаючи з 2012 р. загальна ліквідність сільськогосподарських підприємств майже стабільна і знаходиться у рамках нормативного значення.

Показник робочого капіталу характеризує частину власного капіталу підприємства, яка $є$ джерелом покриття його поточних активів. Динаміка робочого капіталу агропідприємств за період 2012-2017 рр. є позитивною; у 2012 р. величина робочого капіталу становила $0,52 \%$ від загального обсягу активів сільськогосподарських підприємств, у 2017 р. - 0,48\%.

Таблиия 4

Фактичне та нормативне значення показників ліквідності аграрних підприємств України за 2012-2017 рр.,\%

\begin{tabular}{|l|c|c|c|c|c|c|c|}
\hline \multicolumn{1}{|c|}{ Коефіціснти } & Норма & $\mathbf{2 0 1 2}$ & $\mathbf{2 0 1 3}$ & $\mathbf{2 0 1 4}$ & $\mathbf{2 0 1 5}$ & $\mathbf{2 0 1 6}$ & $\mathbf{2 0 1 7}$ \\
\hline $\begin{array}{l}\text { Загальна } \\
\text { ліквідність }\end{array}$ & $1,5-2,5$ & 1,8 & 1,7 & 1,7 & 1,5 & 1,6 & 1,5 \\
\hline $\begin{array}{l}\text { Поточна (швидка) } \\
\text { ліквідність }\end{array}$ & $0,8-2,0$ & 0,2 & 0,9 & 1,13 & 1,17 & 1,17 & 1,05 \\
\hline $\begin{array}{l}\text { Абсолютна } \\
\text { ліквідність }\end{array}$ & $0,20-0,35$ & 0,12 & 0,09 & 0,07 & 0,06 & 0,06 & 0,05 \\
\hline $\begin{array}{l}\text { Частка власного } \\
\text { капіталу }\end{array}$ & $\begin{array}{c}\text { вище } \\
0,50\end{array}$ & 0,52 & 0,51 & 0,41 & 0,40 & 0,48 & 0,48 \\
$\begin{array}{l}\text { Оборотний капітал, } \\
\text { млрд грн }\end{array}$ & вище 0 & 75 & 62 & 104 & 172 & 215 & 223 \\
\hline
\end{tabular}

Джерело: складено автором за даними Державної служби статистики 
Структура оборотного капіталу аграрних підприємств у 2017p. була наступною (рис. 1):

$-31,2 \%$ становили запаси,

$-57,37 \%$ - дебіторська заборгованість,

$-3,13 \%$ - грошові кошти,

$-0,31 \%$ - поточні фінансові інвестиції.

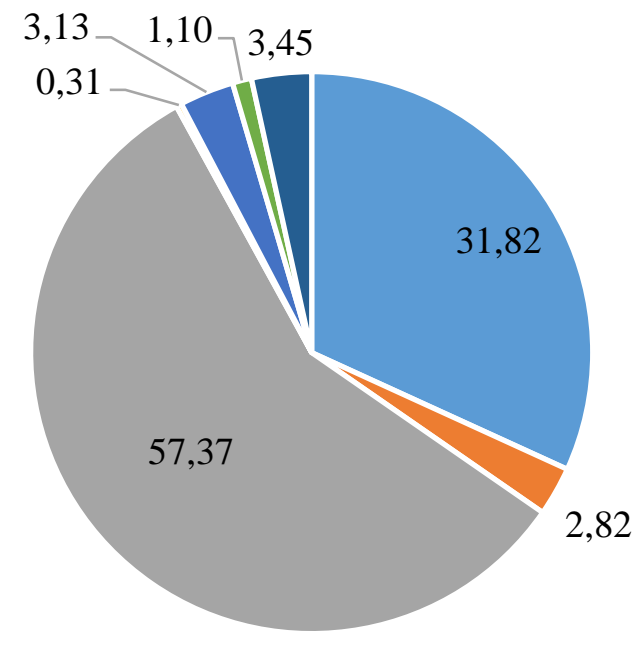

- запаси

- біологічні активи

- дебіторська заборгованість

- фнансові інвестиції

- грошові кошти

• витрати майбутніх періодів

- інші активи

Рuc. 1. Структура оборотного капіталу аграрних підприємств у 2017 p, \%

Джерело: побудовано автором за даними Державної служби статистики

Тобто склад оборотних активів не є оптимальним; частка абсолютно ліквідних активів дуже незначна, що є дестабілізуючим чинником у забезпеченні ліквідності аграрних підприємств.

Більш широкий перелік показників ліквідності, що застосовуються аграрними підприємствами, які проводять детальний фінансовий аналіз, наведено у табл. 5.

Таблиця 5

Фінансові показники ліквідності аграрних підприємств

\begin{tabular}{|c|c|c|c|c|c|c|c|}
\hline \multirow{2}{*}{ Показники } & Розрахунок & \multicolumn{3}{|c|}{ ТОВ «Кернел-трейд» } & \multicolumn{3}{|c|}{ ПАТ Миронівський } \\
\cline { 3 - 8 } & 2 & $\mathbf{2 0 1 7}$ & $\mathbf{2 0 1 6}$ & $\mathbf{2 0 1 5}$ & $\mathbf{2 0 1 7}$ & $\mathbf{2 0 1 6}$ & $\mathbf{2 0 1 5}$ \\
\hline 1 & 2 & 4 & 5 & 6 & 7 & 8 \\
\hline $\begin{array}{c}\text { Ліквідність } \\
\text { загальна }\end{array}$ & $\begin{array}{c}\text { оборотні активи/ } \\
\text { поточні } \\
\text { зобов'язання }\end{array}$ & 1,10 & 1,13 & 1,14 & 0,51 & 0,80 & 0,83 \\
\hline $\begin{array}{c}\text { Ліквідність } \\
\text { поточна }\end{array}$ & $\begin{array}{c}\text { оборотні активи } \\
\text { - запаси)/ } \\
\text { поточні активи }\end{array}$ & 0,81 & 0,68 & 0,62 & 0,49 & 0,74 & 0,79 \\
\hline $\begin{array}{c}\text { Абсолютна } \\
\text { ліквідність }\end{array}$ & $\begin{array}{c}\text { грошові } \\
\text { активи/поточні } \\
\text { зобов'язання }\end{array}$ & 0,29 & 0,25 & 0,22 & 0,28 & 0,41 & 0,32 \\
\hline $\begin{array}{c}\text { Цикл погашення } \\
\text { дебіторської } \\
\text { заборгованості, } \\
\text { рази }\end{array}$ & $\begin{array}{c}\text { дохід від } \\
\text { реалізації/ } \\
\text { дебіторська } \\
\text { заборгованість }\end{array}$ & 3,71 & 8,74 & 12,10 & 4,88 & 1,95 & 2,31 \\
\hline
\end{tabular}


Продовження табл. 5

\begin{tabular}{|c|c|c|c|c|c|c|c|}
\hline 1 & 2 & 3 & 4 & 5 & 6 & 7 & 8 \\
\hline $\begin{array}{c}\text { Цикл погашення } \\
\text { дебіторської } \\
\text { заборгованості, } \\
\text { рази }\end{array}$ & $\begin{array}{c}\text { дохід від } \\
\text { реалізації / } \\
\text { дебіторська } \\
\text { заборгованість }\end{array}$ & 3,71 & 8,74 & 12,10 & 4,88 & 1,95 & 2,31 \\
\hline $\begin{array}{c}\text { Цикл оновлення } \\
\text { запасів, рази } \\
\text { реалізації / } \\
\text { запаси }\end{array}$ & 444,54 & 298,21 & 235,17 & $\begin{array}{c}2062,3 \\
3\end{array}$ & 504,32 & 607,29 \\
\hline $\begin{array}{c}\text { Частка залученого } \\
\text { капіталу в } \\
\text { активах, \% }\end{array}$ & $\begin{array}{c}\text { зобов'язання / } \\
\text { активи }\end{array}$ & 93,11 & 92,95 & 91,33 & 115,60 & 102,80 & 132,75 \\
\hline $\begin{array}{c}\text { Прибутковість, \% } \\
\text { чистий прибуток } \\
\text { /истий дохід } \\
\text { від реалізації }\end{array}$ & 0,84 & 0,43 & 2,91 & 10,10 & 17,78 & 47,99 \\
\hline $\begin{array}{c}\text { Прибуток на } \\
\text { задіяні активи, \% }\end{array}$ & $\begin{array}{c}\text { чистий прибуток } \\
\text { / активи }\end{array}$ & 1,03 & 0,56 & 3,66 & 4,46 & 4,84 & 16,33 \\
\hline
\end{tabular}

Джерело: розраховано за базою даних SMIDA. URL: https://smida.gov.ua/db

Ці підприємства є флагманами аграрного виробництва, але показники їхньої ліквідності досить неоднозначні. За загальною ліквідністю Кернел-Трейд має вдвічі вищі показники, ніж ПАТ Миронівський хлібопродукт. Абсолютна ліквідність у цих підприємств у 2017 році майже однакова - вони можуть погасити поточні борги за рахунок власних ресурсів на $30 \%$.

Для встановлення пропорцій між активами різного ступеня ліквідності і пасивами різного терміну погашення застосовують агрегований баланс (табл. 6), у якому активи і пасиви розподілено на більш і менш ліквідні.

\section{Агрегований баланс для аналізу ліквідності підприємств}

Таблиия 6

\begin{tabular}{|c|c|}
\hline Показник & Розрахунок за даними звітної ф. 1 \\
\hline найбільш ліквідні активи (A1) & p.1160+ p.1165 \\
\hline активи, що швидко реалізуються (А2) & $\begin{array}{l}\text { p. } 1125+\text { p. } 1130+\text { p. } 1135+\text { p. } 1140+\text { p. } 1145+\text { p. } 1155+ \\
\text { p.1190 }\end{array}$ \\
\hline активи, які реалізуються повільно (А3) & p.1100+ p.1170 \\
\hline активи, що важко реалізуються (A4) & p.1095+ p.1200 \\
\hline найбільш термінові зобов'язання (П1) & $\begin{array}{l}\text { p. } 1615+\text { p. } 1620+\text { p. } 1625++ \text { p. } 1630+\text { p. } 1635+ \\
\text { p. } 1640+\text { p. } 1645+\text { p. } 1650+\text { p. } 1660+\text { p. } 1670+\text { p. } 1690\end{array}$ \\
\hline короткострокові зобов’язання (П2) & p. $1600+$ p. $1605+$ p. 1610 \\
\hline довгострокові зобов'язання (П3) & p.1595 \\
\hline власні джерела (П4) & p.1495+ p.1665 \\
\hline умови абсолютної ліквідності балансу & $\mathrm{A} 1 \geq \Pi 1 ; \mathrm{A} 2 \geq \Pi 2 ; \mathrm{A} 3 \geq \Pi 3 ; \mathrm{A} 4 \leq \Pi 4$ \\
\hline
\end{tabular}

Джерело: складено за даними [12]

Як зазначає Г. Терен, інформація фінансової звітності, регламентована НП(С)БО 1, впливає на процес здійснення аналізу, робить його складнішим, оскільки розширено обсяг інформації за рахунок більш глибокої деталізації звітних показників, що дає більші можливості для аналізу динаміки і структури активів, капіталу і зобов'язань, тенденцій змін майнового і фінансового стану підприємства [12].

Більшість аналітиків вважають, що цей Стандарт $є$ кроком назустріч міжнародним стандартам фінансової звітності. 
Схожість процедур збору та аналізу інформації дає змогу для спрощеного доступу навіть міжнародних порівнянь. Це підтверджується зарубіжними дослідниками балансу фермерів. Так A. Plastina досліджує фінансові умови діяльності американських фермерів за коефіцієнтами ліквідності і зазначає, що для фермерських господарств штату Айова вони погіршилися 32012 р., але середні показники ліквідності та платоспроможності залишаються близькими до довгострокового рівня. Дані дослідження розширюють доступність ряду бюджетних ресурсів для фермерів та корисні у їхньому фінансовому плануванні [13].

Дослідниками M. Tóth, Z. Cierna, P. Serences 3 досвіду Європи описано традиційні способи вимірювання ліквідності (абсолютна (грошова), загальна та поточна) для 1100 господарств і встановлено, що типові рекомендовані значення для коефіцієнтів ліквідності не можуть бути використані для сільського господарства, оскільки загальна ліквідність тут значно нижча. Ці дані можна використовувати як еталон для порівняння фінансового стану окремих підприємств [14].

За результатами проведеного дослідження сформовано алгоритм процесу розробки обліково-аналітичного забезпечення управління ліквідністю аграрних підприємств (рис. 2).

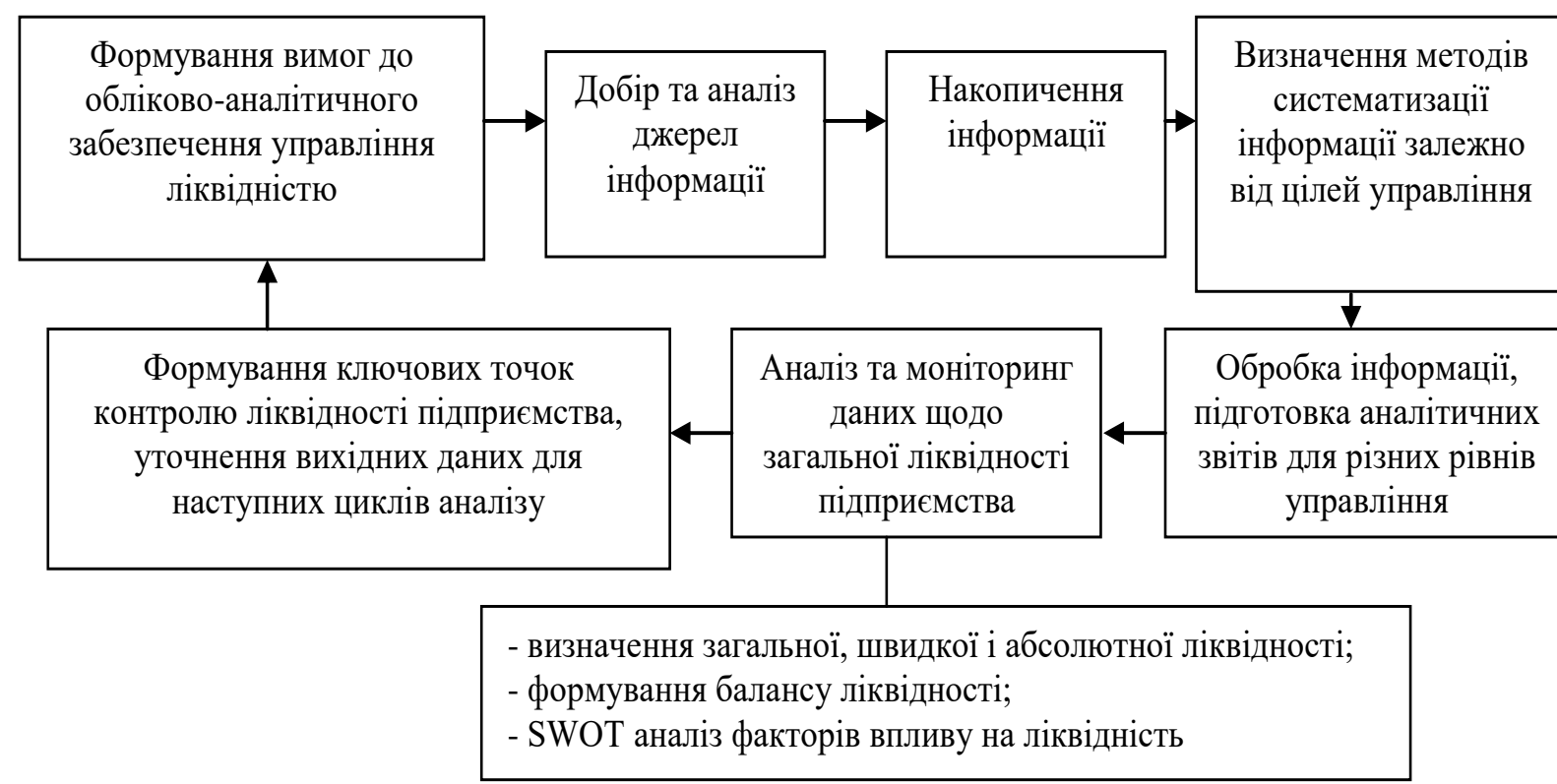

\section{Рис. 2. Алгоритм обліково-аналітичного забезпечення управління ліквідністю аграрних підприсмств \\ Джерело: складено автором за даними: [15].}

Алгоритм інформаційного забезпечення управління ліквідністю передбачає врахування та зворотній вплив на методику ведення обліку і складання фінансової звітності; формування масиву даних для аналізу ліквідності; контроль повноти обліково-аналітичного забезпечення управління ліквідністю аграрних підприємств.

У цьому алгоритмі особливої уваги вимагає блок аналізу та моніторингу даних щодо ліквідності аграрних підприємств. Нами визначено лише три напрями, але реально вони можуть бути розширені до потреб кожного підприємства.

Зокрема, обліково-аналітична система генерує наступні види інформації, що мають важливе значення для управління ліквідністю аграрного підприємства, які мають бути реалізовані на цьому етапі алгоритму: 
-первинна облікова інформація, насамперед про рух грошових коштів та запасів, яка є підставою для прийняття поточних управлінських рішень і зниження фінансових ризиків;

-аналітична інформація, на основі якої формується фінансова звітність, за якою здійснюється аналіз ліквідності та формується баланс ліквідності.

Що стосується SWOT-аналізу факторів управління ліквідністю, необхідно врахувати, що значний вплив на ліквідність мають внутрішні та зовнішні фактори.

Типові причини низької ліквідності аграрних підприємств і заходи їх усунення наведено у табл. 7.

Таблиия 7

Причини низької ліквідності аграрних підприсмств і заходи їх усунення

\begin{tabular}{l} 
Причини низької ліквідності \\
\hline - відсутність послідовного довгострокового планування, \\
що гальмує виробничо-господарські процеси; \\
- неліквідність запасів і готової продукцї̈, що зменшує \\
обсяг обігових коштів;
\end{tabular}

- значний рівень дебіторської і кредиторської заборгованості;

- низький рівень інноваційної активності підприємств;

- невизначеність середовища функціонування (зміна цін на паливно-мастильні матеріали, добрива, пестициди, посівний матеріал);

- сезонність використання ресурсів і отримання доходу від реалізації;

- висока ризиковість втрат майна на стадії незавершеного виробництва;

- недосконалий механізм ціноутворення на сільськогосподарську продукцію, що $є$ причиною недоотримання норми прибутку;

- сезонна зміна цін на продукцію;

- труднощі зберігання зібраного врожаю через брак складських приміщень, елеваторів та забезпечення оптимальних умов зберігання сільськогосподарської продукції;

- сезонність реалізації продукції

Джерело: побудовано автором за даними [5]

Якщо внутрішні - це насамперед, фінансова дисципліна та планування, то зовнішні - це можливість залучення додаткових фінансових ресурсів через банки, кредитні спілки, різні фонди, а також державна підтримка.

Своєю чергою, державна підтримка є особливим фактором і належить до макроекономічних методів фінансового регулювання аграрної галузі.

Розглянуті моменти дають можливість сформувати певні вимоги до системи обліково-інформаційного забезпечення (рис. 3).

Базові елементи обліково-аналітичного забезпечення ліквідності мають передбачати організаційні методи у компетентності кожної системи цього забезпечення. Так, щодо сфери бухгалтерського обліку за видами, до них відносяться: розгорнуте первинне облікове спостереження, вибір об'єктів спостереження для зменшення ризику ліквідності, належне узагальнення за даними 
управлінського та фінансового обліку. До сфери звітності відносяться: достовірне формування даних звітності, можливо $з$ частішою періодичністю, ніж офіційна звітність. Для сфери аналізу: професійне фінансове планування, достатнє фінансове забезпечення, аналітичне узагальнення 3 можливістю побудови моделі аналізу ліквідності аграрних підприємств, формування оптимального балансу власних та позичених коштів з метою підвищення рівня ліквідності.

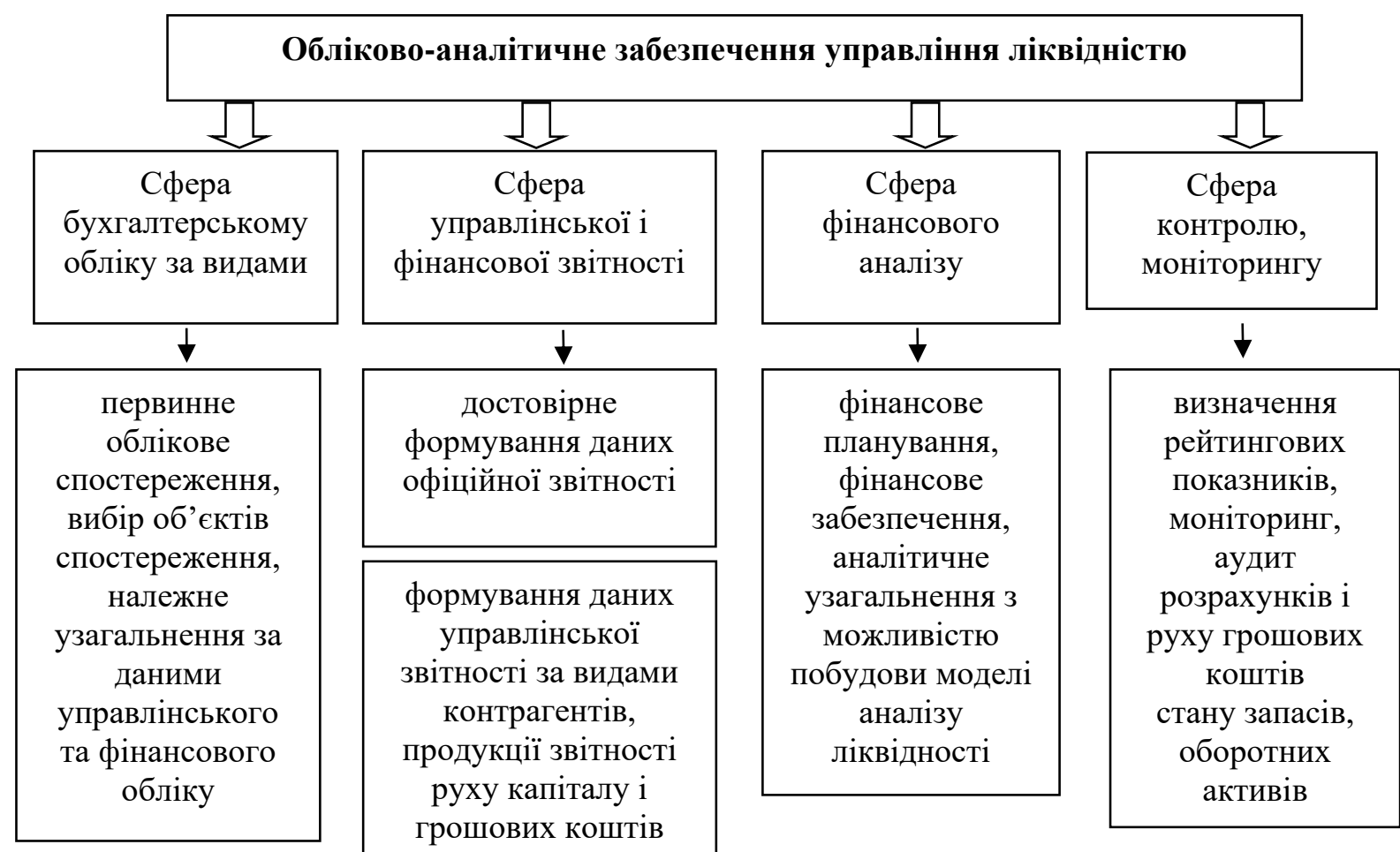

\section{Рис. 3. Вимоги до системи обліково-аналітичного забезпечення управління ліквідністю \\ Джерело: складено автором}

Окрім базових, необхідні також специфічні методи формування інформаційного забезпечення, які ми делегуємо системі контролю. Взявши за основу ідею Л. Очеретько, М. Кончевої [15] щодо системи рейтингової оцінки в обліковоаналітичному забезпеченні, можливо здійснити рейтингову оцінку ризику ліквідності аграрного підприємства. Система показників для рейтингової оцінки ліквідності формується $з$ переліку даних, необхідних для обчислення коефіцієнтів, наведених вище у табл. 3. Класифікація (ранжирування) ризиків ліквідності щодо рейтингу передбачає визначення груп: ризику, небезпеки, благополуччя.

Висновки. Отже, забезпечення сталого економічного розвитку аграрного сектору потребує належного обліково-аналітичного забезпечення управління ліквідністю підприємствами галузі, головним завданням якого виступає забезпечення інформаційних потоків через мінімізацію ризиків неплатежів.

Ліквідність як категорія передбачає здатність і швидкість перетворення різних активів підприємства на грошові кошти, можливість своєчасно погашати зобов'язання, показники якої грунтуються на зіставленні ліквідних активів 3 поточними зобов'язаннями. 


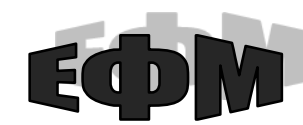

http://efm.vsau.org/

Таким чином, зміст обліково-аналітичного забезпечення управління ліквідністю аграрних підприємств полягає у наданні інформації, забезпеченні даними управління щодо здатності підприємства чи окремих його ланок мобільно і своєчасно знаходити достатні резерви платіжних засобів для виконання фінансових зобов'язань через перетворення активів у засоби платежу 3 використанням усіх елементів обліково-аналітичного арсеналу.

Дослідження свідчать, що чинна методологія аналізу ліквідності підприємства включає розрахунок i аналіз абсолютних i відносних показників, які іiі характеризують. Загалом вона базується на фінансовій звітності, яка з 2013 року максимально наближена до міжнародної. Але при цьому вимагають перегляду норми коефіцієнтів ліквідності. У різних авторів, навіть для аграрної галузі, вони значно коливаються. Ймовірно, необхідно провести аналіз за даними звітності аграрних підприємств і встановити такі показники з врахуванням спеціалізації, регіону, рівня державної підтримки та інших факторів, як це практикується за рубежем. Особливої уваги у цьому плані потребує баланс ліквідності, який теж необхідно максимально адаптувати за показниками до типу і виду аграрного підприємництва.

Сформований алгоритм процесу розробки обліково-аналітичного забезпечення управління ліквідністю аграрних підприємств передбачає ряд послідовних дій по замкненому циклу щодо збору, аналізу, контролю та моніторингу інформації про платоспроможність та фінансову стабільність аграрних підприємств. Важливим блоком цього алгоритму $є$ SWOT-аналіз, для якого нами розширено розглянуто перелік факторів впливу на галузеву ліквідність.

Приведене дослідження може бути корисне на рівні підприємств при формуванні аналітичного забезпечення контролю ліквідності та на рівні державного менеджменту щодо управління фінансовими ресурсами підприємств галузі з метою їх оптимізації.

Подальшими напрямами досліджень проблеми ліквідності є узагальнення чинної практики засобами математичного моделювання та розробка методики визначення ліквідності за ключовими точками контролю.

\section{Список використаних джерел}

1. Калетнік Г.М. Стратегіко-інституційні засади ефективності використання потенціалу аграрного сектору економіки. Економіка. Фінанси. Менеджмент: актуальні питання науки і практики. 2015. №1. С.3-15.

2. Калетнік Г., Козловський С., Козловський В. Стійкість економіки як фактор безпеки та розвитку держави. Економіка України. 2012. № 7. С. 16-25.

3. Гудзенко Н.М., Китайчук Т.Г. Роль обліку в забезпеченні економічної безпеки підприємств. Економіка. Фінанси. Менеджмент: актуальні питання науки і практики. 2017. № 3. С.125-134.

4. Мазур В.А., Томчук О.Ф., Браніцький Ю.Ю. Методика аналізу фінансового стану підприємства відповідно до вимог внутрішніх і зовнішніх користувачів. Економіка. Фінанси. Менеджмент: актуальні питання науки і практики. 2017. №3. С.7-20.

5. Трусова Н. В. Аналіз елементів механізму виникнення кризи ліквідності аграрних підприємств. Збірник наукових праць Таврійського державного агротехнологічного університету (економічні науки). 2013. № 1(3). С. 271-277.

6. Танклевська Н.С. Основи формування фінансової безпеки функціонування сільського господарства як базису економічного розвитку. Науковий вісник НУБІП України: серія Економіка, аграрний менеджмент, бізнес. 2015. № 222. С.15-20. 
7. Правдюк Н.Л., Мулик Т.О., Мулик Я.І. Управління фінансовою безпекою підприємств: обліково-аналітичний аспект. Монографія. Київ: «Центр учбової літератури», 2018. 224 с.

8. Халатур С.М. Бровко Л.І., Моруга Т.О. Методологія оцінки ліквідності та платоспроможності сільськогосподарських . Економіка та держава. 2017. № 12. С. 56-60.

9. Правдюк Н.Л., Правдюк М.В. Якість облікової інформації: сутність та методика оцінки. Облік і фінанси. № 2 (72). 2016. С.57-65.

10. Правдюк Н.Л. Обліково-аналітичне забезпечення управління прибутком підприємства. Облік і фінанси. 2015. № 4 (70). С.53-60.

11. Чайка Т.Ю., Александрова В.О., В.В. Бабіч. Платоспроможність, ліквідність і фінансова стійкість: теоретичні і методичні аспекти аналізу. Вісник Національного технічного університету «ХПІ» (економічні науки) Bulletin of the National Technical University «KhPI» (economic sciences) : зб. наук. пр. Харків : НТУ «ХПІ», 2018.№ 37 (1313). С. 82-89.

12. Терен Г.М. Система методологічних елементів аналізу ліквідності сільськогосподарського підприємства. Агросвіт. 2017. № 21. С. 30-34.

13. Plastina A. Financial stress in Iowa farms: 2014-2016. 2017. DOI https://doi.org/10.31274/icm-180809-260.

14. Tóth M., Cierna Z., Serences P. Benchmark values for liquidity ratios in Slovak agriculture //Acta Scientiarum Polonorum. Oeconomia. 2013. T. 12. №. 3.

15. Лемішко О.О. Ліквідність сільськогосподарських підприємств у сучасних умовах господарювання. Вісник аграрної науки. 2014. № 12. С. 56-59.

16. Очеретько Л. М., Кончева М. О. Формування обліково-інформаційного забезпечення управління дебіторською заборгованістю підприємства. Сталий розвиток економіки. 2015. № 2. С. 221-226.

\section{References}

1. Kaletnik, G.M. (2015). Stratehiko-instytucijni zasady efektivnosti vykoristannja potencialu ahrarnoho sektoru ekonomiki [Strategic-institutional principles of efficiency of using the potential of agrarian sector of the economy]. Ekonomika. Finansy. Menedzhment: aktual'ni pytannja nauky i praktyky - Economy. Finances. Management: topical issues of science and practice, 1, 3-15 [in Ukrainian].

2. Kaletnik, H. M., Kozlivskyi, S.V., \& Kozlivskyi, V.O. (2012). Stiikist ekonomiky yak factor bezpeky ta rozvytku derzhavy [Sustainability of theeconomy as a factor of security and development of the state]. Ekonomika Ukrainy - Ukraine economy, 7, 16-25 [in Ukrainian].

3. Hudzenko, N.M., \& Kytaychuk, T.H. (2017). Rol obliku v zabezpecheni Ekonomichnoi bezpeky pidpryiemstv [The role of accounting in ensuring the economic security of enterprises]. Ekonomika. Finansy. Menedzhment: aktual'ni pytannja nauky $i$ praktyky -Economy. Finances. Management: topical issues of science and practice, 3, 125134 [in Ukrainian].

4. Mazur, V.A., \& Tomchuk, O.F., Branic'kij, Ju.Ju. (2017). Metodyka analizu finansovogo stanu pidpriemstva vidpovidno do vimog vnutrishnih $i$ zovnishnih koristuvachiv [Methodology for analyzing the financial condition of an enterprise in 
accordance with the requirements of internal and external users]. Ekonomika. Finansy. Menedzhment: aktual'ni pitannja nauky i praktyky - Economy. Finances. Management: topical issues of science and practice, 3, 7-20 [in Ukrainian].

5. Trusova, N.V. (2013). Analiz elementiv mehanizmu vynyknennja kryzy likvidnosti agrarnih pidpriemstv [Analysis of elements of the mechanism of the crisis of liquidity of agrarian enterprises]. Zbirnik naukovih prac' Tavrijs'kogo derzhavnogo agrotehnologichnogo universitetu (ekonomichni nauki) - Collection of scientific works of the Taurian state agrotechnological university (economic sciences), 1(3), 271-277 [in Ukrainian].

6. Tanklevs'ka, N.S. (2015). Osnovi formuvannja finansovoï bezpeky funkcionuvannja sil's'kogo gospodarstva jak bazisu ekonomichnogo rozvitku [Fundamentals of Financial Security Functioning of Agriculture Functioning as a Basis for Economic Development]. Naukovij visnik NUBIP Ukrä̈ni: serija Ekonomika, agrarnij menedzhment, biznes - Scientific Bulletin of NUBIP of Ukraine: Series Economics, Agrarian Management, Business, 222, 15-20 [in Ukrainian].

7. Pravdjuk, N.L., \& Mulyk, T.O., Mulyk, Ja.I. (2018). Upravlinnja finansovoju bezpekoju pidpriєmstv: oblikovo-analitichnij aspekt: monografija. [Management of financial security of enterprises: accounting and analytical aspect: monograph]. Kiïv: «Centr uchbovoï literaturi», 224 [in Ukrainian].

8. Halatur, S.M. \& Brovko, L.I., Moruga, T.O. (2017). Metodologija ocinki likvidnosti ta platospromozhnosti sil's'kogospodars'kih [Methodology of estimation of liquidity and solvency of agriculture]. Ekonomika ta derzhava-Economy and the state, 12, 56-60 [in Ukrainian].

9. Pravdjuk, N. L., \& Pravdjuk, M. V. (2016). Jakist' oblikovoï informaciï: sutnist' ta metodika ocinki [Quality of accounting information]. Oblik $i$ finansi-Accounting and finance, 2 (72), 57-65 [in Ukrainian].

10. Pravdiuk, N.L. (2015). Oblikovo-analitychne zabezpechennia upravlinnia prybytkom pidpryiemstva [Accounting and analytical support for management of enterprise profits]. Oblik $i$ finansy - Accounting and finance, 4, 53-60 [in Ukrainian].

11. Chajka, T.Ju., \& Aleksandrova, V.O., Babich, V.V. (2018). Platospromozhnist', likvidnist' i finansova stijkist': teoretichni i metodychni aspekty analizu [Liquidity and financial stability: theoretical and methodological aspects of analysis]. Visnyk Nacional'nogo tehnichnogo universitetu "HPI" (ekonomichni nauky) - Bulletin of the National Technical University "KhPI" (economic sciences). Kharkiv: NTU «KhPI», 37 (1313), 82-89 [in Ukrainian].

12. Teren, G.M. (2017). Systema metodologichnih elementiv analizu likvidnosti sil's'kogospodars'kogo pidpriemstva [System of methodological elements of the analysis of liquidity of an agricultural enterprise]. Agrosvit-Agricultural world, 21, 30-34 [in Ukrainian].

13. Plastina, A. (2017). Financial stress in Iowa farms: 2014-2016. DOI https://doi.org/10.31274/icm-180809-260.

14. Tóth, M., \& Cierna, Z., Serences, P. (2013). Benchmark values for liquidity ratios in Slovak agriculture. Acta Scientiarum Polonorum. Oeconomia, 12, 3.

15. Lemishko, O.O. (2014). Likvidnist' sil's'kogospodars'kih pidpriemstv u suchasnih umovah gospodarjuvannja [Liquidity of agricultural enterprises in modern economic conditions. Visnik agrarnoï naukiy-Bulletin of Agrarian Science, 12, $56-59$ [in Ukrainian]. 
16. Ocheret'ko, L.M., \& Koncheva, M.O. (2015). Formuvannja oblikovoinformacijnogo zabezpechennja upravlinnja debitors'koju zaborgovanistju pidpriemstva [Formation of accounting and information management of accounts receivable enterprise]. Stalyj rozvytok ekonomiky - Sustainable development of the economy, 2, 221-226 [in Ukrainian].

\section{Відомості про автора}

ПРАВДЮК Марина Володимирівна - кандидат економічних наук, старший викладач кафедри обліку та оподаткування в галузях економіки, Вінницький національний аграрний університет (21008, м.Вінниця, вул.Сонячна, 3, e-mail: a.Pravd4449@gmail.com).

PRAVDIUK Maryna - Candidate of Economic Sciences, Senior Lecturer of the Department of Accounting and Taxation in the Economy, Vinnytsia National Agrarian University (21008, 3 Sonyachna Str., Vinnytsia, e-mail: a.pravd4449@gmail.com).

ПРАВДЮК Марина Владимировна - кандидат экономических наук, старший преподаватель кафедры учёта и налогообожения в отраслях экономики, Винницкий национальный аграрный университет $(21008$, г. Винница, ул. Солнечная, 3, e-mail: a.pravd4449@gmail.com).

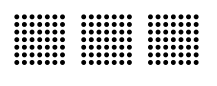

